\title{
Gold recovery from waste electrical and electronic equipment by electrodeposition: A feasibility study
}

\author{
M. Lekka ${ }^{\text {a,* }}$, I. Masavetas ${ }^{\text {b }}$, A.V. Benedetti ${ }^{\text {c }}$, A. Moutsatsou ${ }^{\text {b }}$, L. Fedrizzi ${ }^{\text {a }}$ \\ a Department of Chemistry, Physics and Environment, University of Udine, Via del Cotonificio 108, 33100 Udine, Italy

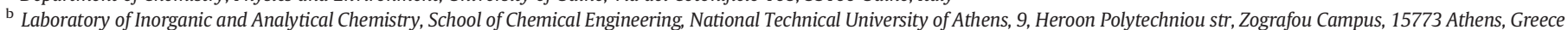 \\ c Instituto de Quimica de Araraquara, Universidade Estadual Paulista Julio Mesquita Filho of Brazil, Campus de Araraquara, Brazil
}

\section{A R T I C L E I N F O}

\section{Article history:}

Received 28 February 2015

Received in revised form 1 June 2015

Accepted 28 July 2015

Available online 31 July 2015

\section{Keywords:}

Gold recovery

Electrodeposition

Leaching

PCBs

\begin{abstract}
A B S T R A C T
Due to rapid technological progress, the replacement of electronic equipment is very often necessary, leading to huge amounts that end up as waste. Printed circuit boards (PCBs) constitute a unique section among Waste Electrical and Electronic Equipment (WEEE), due to their content in precious and high commercial value metals. Gold, among them, is usually present in a very low quantity and its recovery requires complex chemical treatments. The aim of this work is to evaluate the feasibility of recovering Au by electrodeposition from aqueous solutions obtained after leaching of PCBs and electrical contacts prior to the recovery of any other metals. Aqua regia was used as a leachant for the powders obtained after mechanical and thermal treatment of PCBs' and contacts' parts. The leaching solutions have been analysed by ICP in order to detect the most important metals for the electrodeposition. A preliminary study using synthetic solutions of the elements which could interfere with the gold deposition was performed, followed by an electrochemical study of leach solution of PCBs and contacts. The deposition potential of gold was determined in each solution and a short potentiostatic deposition was carried out. The obtained deposits have been observed by SEM and analysed by EDXS in order to confirm the deposition and to evaluate the purity of the obtained deposits. Aqua regia was proved to be an efficient leachant for the dissolution of all metals from powders obtained after thermal treatment of PCBs and contacts. Among the metals present in the leach solution only copper can interfere with the deposition of gold as the reduction peaks of the auric chloride complex and the $\mathrm{Cu}^{2+}$ ions are very close. However, the deposition of Au was possible, even with low efficiency. The deposition rate increases by increasing the temperature at $40^{\circ} \mathrm{C}$ and the stirring of the electrolyte. A compact nanocrystalline deposit of high purity gold has been obtained by electrodeposition at $0.55 \mathrm{~V}$ vs. Ag/AgCl/ $\mathrm{KCl}_{3 \mathrm{M}}$ from the contacts' leach solution. Therefore, this study demonstrates the feasibility of gold recovery from PCBs' and contacts' leach solutions by electrodeposition, without any further chemical treatment.
\end{abstract}

(C) 2015 Elsevier B.V. All rights reserved.

\section{Introduction}

Due to rapid technological progress, the replacement of electronic equipment is very often necessary, leading to huge amounts that end up as waste. The hazardous content of Waste Electrical and Electronic Equipment (WEEE) is a cause for concern, since it is often discarded in municipal waste land-field, from where it may enter the aquifer. The recycling of this type of scrap is still quite limited due to the heterogeneity of materials. Among these wastes, computers appear to be distinctive, as far as further exploitation is concerned. According to studies carried out, computers seem to be the only WEEE category that could allow a recycling process scheme to be financially beneficial. Printed

\footnotetext{
* Corresponding author.

E-mail addresses: maria.lekka@uniud.it (M. Lekka), iliasmasav@yahoo.gr (I. Masavetas), benedeti@iq.unesp.br (A.V. Benedetti), angst@central.ntua.gr (A. Moutsatsou) lorenzo.fedrizzi@uniud.it (L. Fedrizzi).
}

circuit boards (PCBs) constitute a unique section among WEEE, due to their content in precious and high commercial value metals (Masavetas and Moutsatsou, 2009). In general, PCB scrap contains approximately 40\% metals, 30\% plastics and 30\% ceramics (Cui and Forssberg, 2003; Linton, 2000; Sum, 1991; Zhang and Fosseberg, 1997).

Considering all the above, the European Parliament issued directives 2002/95/EC and 2003/95/EC (Directive 2002/95/EC, 2003; Directive 2003/95/EC, 2003) setting definitions, guidelines for the restriction of use of certain hazardous substances and goals for the recycling of WEEE. Since then, there have been revised versions of these base directives, emerging from the evaluation of the achieved progress, variation of needs and requirement to stay in tune with the rapid evolution in the field. It is worth noting, as a vivid example, that directive 2011/65/ EU (Directive 2011/65/EU, 2011) states that the restriction of use of hazardous substances in WEEE doesn't apply to "equipment designed to be sent to space". The latest directive 2012/19/EU (Directive 2012/ 19/EU, 2012) sets an ambitious $70-85 \%$ collection percentage target and $50-75 \%$ recycling percentage target, depending on the category of 
equipment and with an upward trend from 2012 up to 2018. Achieving these goals would mean that 10 million tons, or roughly $20 \mathrm{~kg}$ per capita, must have been collected, as opposed to the initial target of $4 \mathrm{~kg}$ per capita. With a prognosis of 12 million tons of WEEE to be produced in the EU in 2020 (http://ec.europa.eu/environment/waste/ weee/index_en.htm), it is clear that methods of treatment of these waste demonstrate great interest.

The methods that can be applied in order to recover metals from computers are basically the physical/mechanical (Cui and Forssberg, 2003) and the chemical separation. As far as chemical separation is concerned, pyrometallurgy, hydrometallurgy and electrodeposition are most commonly used. Pyrometallurgical processes, however, have the drawback of producing excessive amounts of pollutants and large quantities of slag-rich base metal. Usually hydrometallurgical metal recovery requires elaborate procedures involving precipitation and extraction with a wide range of reagents. From the environmental and financial points of view electrodeposition is a less expensive and simple method to recover metals from electronic scrap. The drawback of this method is that often it is not possible to perform a selective electrodeposition from aqueous media containing different metals. Several groups have studied the electrochemical recovery of $\mathrm{Cu}$, which is the metal found in higher amounts in the PCBs (Masavetas et al., 2009; Mecucci and Scott, 2002; Oishi et al., 2007; Veit et al., 2006) after chemical treatments in order to eliminate the other metals first or at least decrease their concentration in the leaching solution.

Precious metals such as Ag, Pd and Au are also present in the WEEE. Precious metals in PCBs account for more than $80 \%$ of the total intrinsic value even though their amount is less than $1 \mathrm{wt} . \%$ which increases the interest for their recovery. Very few works can be found in literature regarding the recovery of precious metals from WEEE and even less for Au. Khaliq et al. (2014) summarised the hydrometallurgical recovery of precious metals of e-waste. Qinet et al. (2005) separated Au, Ag, Pd and $\mathrm{Cu}$ from printed circuit boards using a multistep procedure including an oxidative sulphuric acid leach to dissolve copper and part of the silver, an oxidative chloride leach to dissolve palladium and copper and cyanidation to recover gold, silver and palladium. The metal recovery was performed using cementation, precipitation, ion exchange and carbon adsorption. Sheng and Etsell (2007) extracted gold from computer circuit board scrap in a three step process using aqua regia as leachant and recovering gold from the solution through precipitation with ferrous sulphate. Park and Fray (2009) studied a method for the recovery of $\mathrm{Ag}$, Au and Pd from the residue solution after the recovery of $\mathrm{Cu}$. The method contains leaching with aqua regia, where $\mathrm{Ag}$ is stable, precipitation of Pd and recovery of Au in nanoparticles form using liquid-liquid extraction with toluene. Furthermore, Barbieri et al. (2010) have proposed a method for the separation of precious metals which is based on the oxidation of the other metals by a milder etching agent.

The aim of this work is to evaluate the possibility of recovering Au with electrodeposition from aqueous solution obtained after leaching of PCBs in the presence of various other metals.

\section{Experimental}

\subsection{Preparation of leach solutions}

Printed circuit boards (PCBs) from personal computers were used as a raw material. Firstly, the PCBs were mechanically cut into smaller pieces of about $2 \times 2 \mathrm{~cm}$. Afterwards a thermal pre-treatment was carried out for the separation of the non-metallic parts (Masavetas et al., 2009). The PCB pieces were heated into an electrical furnace at $500{ }^{\circ} \mathrm{C}$ for a period of $1 \mathrm{~h}$. During the heating, a loss on ignition of approximately $22 \%$ took place. The treated samples have undergone Thermogravimetric Analysis (TG) (Mettler Toledo TGA/SDTA851e) and no mass loss was detected, proving that the treating time and temperature were sufficient to remove the non-metallic parts. This process was very important for further treatment, since it removed the non-metallic parts of the
Table 1

Chemical composition of the powder samples obtained from PCBs and contacts as determined by XRF.

\begin{tabular}{lll}
\hline Component & \% PCBs & \% contacts \\
\hline $\mathrm{Ca}$ & 20.80 & 41.31 \\
$\mathrm{Si}$ & 39.50 & 22.10 \\
$\mathrm{Cu}$ & 17.00 & 22.44 \\
$\mathrm{Sn}$ & 3.10 & \\
$\mathrm{~Pb}$ & 4.10 & \\
$\mathrm{Br}$ & & 7.67 \\
$\mathrm{Ni}$ & 0.90 & 1.59 \\
$\mathrm{Fe}$ & 0.70 & 0.78 \\
$\mathrm{Zn}$ & 1.10 & 0.23 \\
$\mathrm{Ti}$ & 0.50 & 0.75 \\
$\mathrm{Sr}$ & & 0.36 \\
$\mathrm{Ag}$ & $930 \mathrm{ppm}$ & \\
$\mathrm{Au}$ & & 0.35 \\
\hline
\end{tabular}

samples, resulting in a more effective dissolution. The treated samples were ground in a lab-mill apparatus (FRITSCH pulverisette 2) for 5 min, which led to powder samples, entirely passing the $90 \mu \mathrm{m}$ sieve. The same procedure was followed using only the contacts' part of the PCBs which is more concentrated in Au.

The composition of the obtained powder samples, as determined by X-ray fluorescence (XRF) (THERMO A.R.L. ADVANT'XP), is presented in Table 1 (Masavetas and Moutsatsou, 2011).

$2 \mathrm{~g}$ of each type of powder has been then dissolved in $40 \mathrm{~mL}$ of aqua regia ( $30 \mathrm{~mL}$ of concentrated $\mathrm{HCl}$ and $10 \mathrm{~mL}$ of concentrated $\mathrm{HNO}_{3}$ ) and heated to $80{ }^{\circ} \mathrm{C}$ under continuous stirring for $1 \mathrm{~h}$. The solutions have been diluted to final volume of $200 \mathrm{~mL}$ and the $\mathrm{pH}$ adjusted to 4 using $\mathrm{KOH}$. Previous attempts have been made without adjusting the $\mathrm{pH}$ (obtained value around 0 ) and by adjusting the $\mathrm{pH}$ with $\mathrm{NH}_{4} \mathrm{OH}$ to the value of 9. In the first case there was a dissolution of the obtained gold on the cathode electrode due to the very low $\mathrm{pH}$ of the solution and in the second strong precipitation phenomena occurred after 2-3 days. The obtained solutions have been analysed by Inductively Coupled Plasma Spectroscopy (ICP) (Jobin Yvon JY 38 PLUS) regarding the most interesting metals for electrodeposition. The calibration has been performed using 5 standards for each element with concentrations varying from $1 \mathrm{mg} / \mathrm{L}$ to $40 \mathrm{mg} / \mathrm{L}$. For the determination of $\mathrm{Pb}$, Sn and $\mathrm{Zn}$ the leach solutions have been diluted at 1:10 while for the determination of $\mathrm{Cu}$ at 1:100. For the determination of Au no dilution has been performed.

\subsection{Preparation of synthetic solutions}

As the dissolved species of most of these metals have multiple oxidation states and the reduction mechanisms of some are not fully comprehended it has been decided to prepare "single-metal" solutions of all the metals that could influence the reduction of $\mathrm{Au}$ in order to study, separately at first, the reduction of each of these metals in the same environment. Synthetic electrolytes were prepared from analytical grade chemicals and de-ionised water. Concentrated acids $\mathrm{HCl}$ (37 wt.\%) and $\mathrm{HNO}_{3}$ (65 wt.\%) have been used to prepare the aquaregia, $\mathrm{CuSO}_{4}, \mathrm{SnCl}_{2}$ and $\mathrm{ZnCl}_{2}$ have been used for $\mathrm{Cu}, \mathrm{Sn}$ and $\mathrm{Zn}$ while Au solutions have been prepared by dissolving solid $\mathrm{Au}$ in aqua-regia. The $\mathrm{pH}$ has been adjusted to 4 using $\mathrm{KOH}$. The prepared synthetic solutions are listed in Table 2.

Table 2

Synthetic solutions.

\begin{tabular}{ll}
\hline Solution name & Composition \\
\hline "Blank" & $150 \mathrm{~mL} / \mathrm{L} \mathrm{HCl}, 50 \mathrm{~mL} / \mathrm{L} \mathrm{HNO}_{3}$ \\
"Sn" & $150 \mathrm{~mL} / \mathrm{L} \mathrm{HCl}, 50 \mathrm{~mL} / \mathrm{L} \mathrm{HNO}_{3}, 250 \mathrm{ppm} \mathrm{Sn}$ \\
"Zn" & $150 \mathrm{~mL} / \mathrm{L} \mathrm{HCl}, 50 \mathrm{~mL} / \mathrm{L} \mathrm{HNO}_{3}, 150 \mathrm{ppm} \mathrm{Zn}$ \\
"Cu" & $150 \mathrm{~mL} / \mathrm{L} \mathrm{HCl}, 50 \mathrm{~mL} / \mathrm{L} \mathrm{HNO}, 2000 \mathrm{ppm} \mathrm{Cu}$ \\
"Au" & $150 \mathrm{~mL} / \mathrm{L} \mathrm{HCl}, 50 \mathrm{~mL} / \mathrm{L} \mathrm{HNO}_{3}, 100 \mathrm{ppm} \mathrm{Au}$ \\
"Cu + Au" & $150 \mathrm{~mL} / \mathrm{L} \mathrm{HCl}, 50 \mathrm{~mL} / \mathrm{L} \mathrm{HNO}_{3}, 2000 \mathrm{ppm} \mathrm{Cu}, 100 \mathrm{ppm} \mathrm{Au}$ \\
\hline
\end{tabular}


Table 3

Concentrations of the main metals in the leach solutions as determined by ICP.

\begin{tabular}{lcc}
\hline Component & $\begin{array}{c}\text { Concentration in the PCB leach } \\
\text { solution }(\mathrm{mg} / \mathrm{L})\end{array}$ & $\begin{array}{c}\text { Concentration in the contacts } \\
\text { leach solution }(\mathrm{mg} / \mathrm{L})\end{array}$ \\
\hline $\mathrm{Cu}$ & $1496 \pm 7$ & $10,066 \pm 18$ \\
$\mathrm{Sn}$ & $935 \pm 5$ & $18.5 \pm 0.4$ \\
$\mathrm{Zn}$ & $758 \pm 4$ & $7.3 \pm 0.1$ \\
$\mathrm{Au}$ & $16.1 \pm 0.2$ & $99.7 \pm 0.5$ \\
$\mathrm{Ni}$ & $100 \pm 2$ & $30 \pm 0.4$ \\
$\mathrm{Al}$ & $20 \pm 0.3$ & $80 \pm 0.5$ \\
$\mathrm{Fe}$ & $1300 \pm 8$ & $10 \pm 0.2$ \\
$\mathrm{~Pb}$ & $960 \pm 9$ & $4 \pm 0.5$ \\
\hline
\end{tabular}

\subsection{Electrochemical measurements}

Cyclic voltammetric tests have been performed in parallel plate geometry with a three electrode system. A Pt disc was used as working electrode, a Pt coated Ti grid as counter electrode and a $\mathrm{Ag} / \mathrm{AgCl} / \mathrm{KCl}_{3 \mathrm{M}}$ electrode as reference. The potential scan rate was $20 \mathrm{mV} / \mathrm{s}$.

The electrodeposition was carried out using the same cell geometry under potential control and the obtained deposits have been observed under Scanning Electron Microscopy (Zeiss model EVO 40).

\section{Results and discussion}

\subsection{Chemical analyses of leach solutions}

The ICP analyses results are reported in Table 3. As can be observed among the dissolved metals copper has the highest concentration in both leach solutions, while the concentration of Au is quite low. The contact solution presents an order of magnitude higher concentration at both $\mathrm{Cu}$ and $\mathrm{Au}$ as compared to the PCB solution. This is due to the fact that contacts are mainly composed of copper covered by a gold deposit. Sn and $\mathrm{Zn}, \mathrm{Ni}$ and Fe are mainly present in other PCB parts. The results are in agreement with the chemical composition of the powder samples as determined by XRF (Table 1 ). From all the above elements $\mathrm{Au}, \mathrm{Cu}, \mathrm{Zn}$ and $\mathrm{Sn}$ have been studied separately as their presence could influence the gold deposition.

\subsection{Cyclic voltammetry in single metal synthetic solutions}

The cyclic voltammograms, obtained in both the blank solution and the Sn solution are reported in Fig. 1. The measurement in the blank solution has been performed in order to obtain a "base-line" for all the following voltammograms. The anodic current peak observed at about $1.2 \mathrm{~V}$ vs. $\mathrm{Ag} / \mathrm{AgCl} / \mathrm{KCl}_{3 \mathrm{M}}$ corresponds probably to Pt dissolution in chloride medium and to the formation of Pt oxides; the formation of $\mathrm{Pt}$ oxides is disturbed by the high $\mathrm{Cl}^{-}$concentration that competes with water on the Pt surface. When the scan is reversed the cathodic current peak at about $0.95 \mathrm{~V} \mathrm{vs}$. $\mathrm{Ag} / \mathrm{AgCl} / \mathrm{KCl}_{3 \mathrm{M}}$ corresponds to the reduction of the oxidized Pt species previously formed. At potentials lower than $-0.8 \mathrm{~V}$ vs. $\mathrm{Ag} / \mathrm{AgCl} / \mathrm{KCl}_{3 \mathrm{M}}$ the formation of $\mathrm{H}_{2}$ is observed according to the reaction:

$2 \mathrm{H}^{+}+2 \mathrm{e}^{-} \rightarrow \mathrm{H}_{2}$.

And in the anodic scan at around $-0.9 \mathrm{~V}$ vs. $\mathrm{Ag} / \mathrm{AgCl} / \mathrm{KCl}_{3 \mathrm{M}}$ the oxidation of $\mathrm{H}_{2}$ occurs (Angerstain-Kozlowska et al., 1995; Sawyer et al., 1995). By comparing the two voltammograms of Fig. 1 no differences can be noticed demonstrating that $\mathrm{Sn}$ is not involved in any electrochemical reaction in the scanned potential range.

The cyclic voltammogram obtained in the $\mathrm{Zn}$ solution is reported in Fig. 2 compared to the voltammogram of the blank solution. As can be observed the presence of $\mathrm{Zn}$ ions in the solution shifted the potential of the formation of $\mathrm{H}_{2}$ to more negative values. In this case there is a possible deposition of $\mathrm{Zn}$ at the same range of potential values as the proton reduction that has been previously demonstrated (Horányi and Aramata, 1997; Mascaro et al., 2002).

The cyclic voltammogram obtained in the $\mathrm{Cu}$ solution is reported in Fig. 3 compared to the one of the blank solution. Two reduction peaks and two oxidation peaks are present in the $\mathrm{Cu}$ solution voltammogram. Moreover, the hydrogen evolution reaction moved toward more positive potentials as can be observed by the overlapping of the curve compared to the one obtained in the blank solution. To better understand the four peaks of $\mathrm{Cu}$, different cyclic voltammograms have been obtained using lower potential ranges. By observing Fig. 4 it is clear that the oxidation peak at $0.27 \mathrm{~V}$ vs. $\mathrm{Ag} / \mathrm{AgCl} / \mathrm{KCl}_{3 \mathrm{M}}$ corresponds to the reduction peak observed at $0.14 \mathrm{~V}$ vs. $\mathrm{Ag} / \mathrm{AgCl} / \mathrm{KCl}_{3 \mathrm{M}}$ and it refers to a

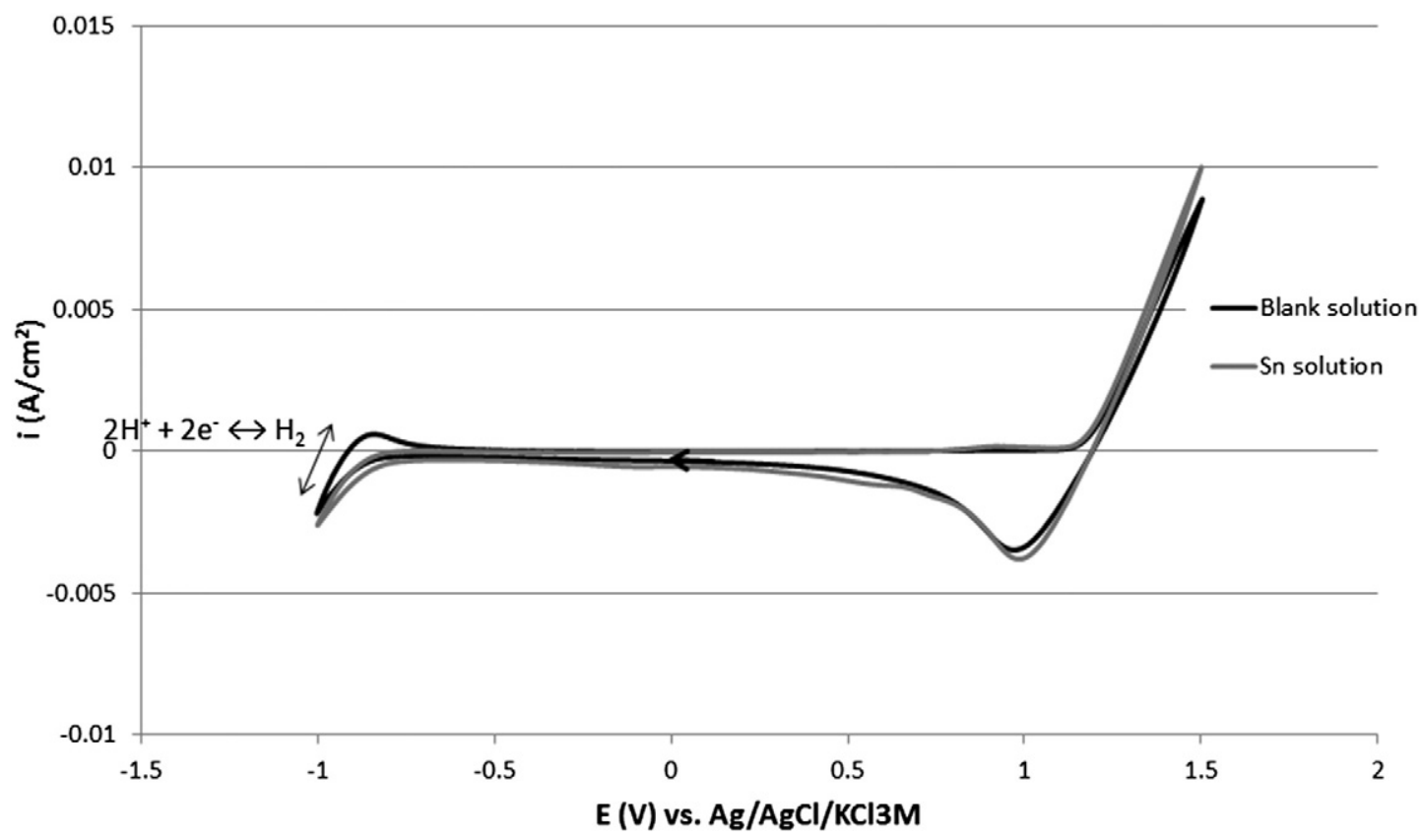

Fig. 1. Cyclic voltammograms obtained in the "blank" and "Sn" synthetic solutions. 


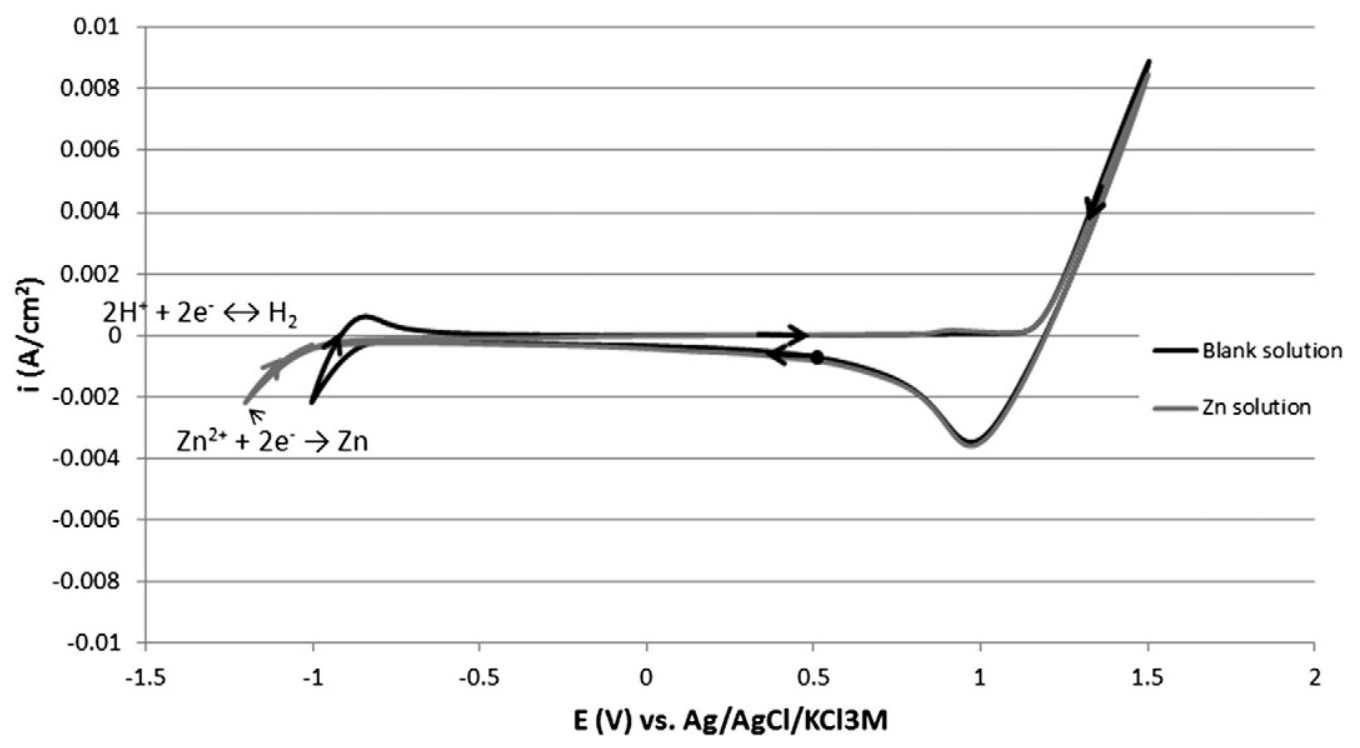

Fig. 2. Cyclic voltammograms obtained in the "blank" and "Zn" synthetic solutions.

redox reaction which occurs on the electrode surface involving only soluble species. No nucleation occurs as can be deduced from the grey curve in Fig. 4. Indeed when the scan was reversed at the initial of the current decay the cathodic current was lower than in the direct scan. The possible global anodic and cathodic reactions could be:

$\mathrm{Cu}^{2+}+2 \mathrm{Cl}^{-}+\mathrm{e}^{-} \leftrightarrow \mathrm{CuCl}_{2}^{-}$

As can be observed from Fig. 5 the reduction peak at about $-0.2 \mathrm{~V}$ vs. $\mathrm{Ag} / \mathrm{AgCl} / \mathrm{KCl}_{3 \mathrm{M}}$ corresponds to the oxidation peak at about $0.02 \mathrm{~V}$ vs. $\mathrm{Ag} / \mathrm{AgCl} / \mathrm{KCl}_{3 \mathrm{M}}$. The shape of the second cathodic peak is completely different from the first one, since the current decay is fast at the beginning of the peak. When the scan was reversed at the initial of the current decay the cathodic current was higher than in the direct scan indicating an increase of the active area due to the nucleation process of metallic copper on the Pt electrode. The cathodic current peak at about $-0.2 \mathrm{~V}$ vs. $\mathrm{Ag} / \mathrm{AgCl} / \mathrm{KCl}_{3 \mathrm{M}}$ corresponds thus to the metallic copper deposition and the anodic current peak at about $0.02 \mathrm{~V}$ vs. $\mathrm{Ag} / \mathrm{AgCl} / \mathrm{KCl}_{3 \mathrm{M}}$ to $\mathrm{Cu}^{0}$ dissolution mainly via

$\mathrm{CuCl}_{2}^{-}+\mathrm{e}^{-} \rightarrow \mathrm{Cu}^{0}+2 \mathrm{Cl}^{-}$(reduction reaction)

$\mathrm{Cu}^{0}+\mathrm{Cl}^{-} \rightarrow \mathrm{CuCl}_{\mathrm{ads}}+\mathrm{e}^{-}$(oxidation reaction)

followed by the

$\mathrm{CuCl}_{\mathrm{ads}}+\mathrm{Cl}^{-} \leftrightarrow \mathrm{CuCl}_{2}^{-}$.

Therefore, the cathodic current peaks at about $0.11 \mathrm{~V}$ and $-0.2 \mathrm{~V}$ vs. $\mathrm{Ag} / \mathrm{AgCl} / \mathrm{KCl}_{3 \mathrm{M}}$ and their corresponding anodic current peaks at $0.27 \mathrm{~V}$ and $0.06 \mathrm{~V}$ (Fig. 3) are related to the processes described in Eqs. (2)-(5). These reactions were also proposed for explaining the copper/chloride interface behaviour in different chloride containing

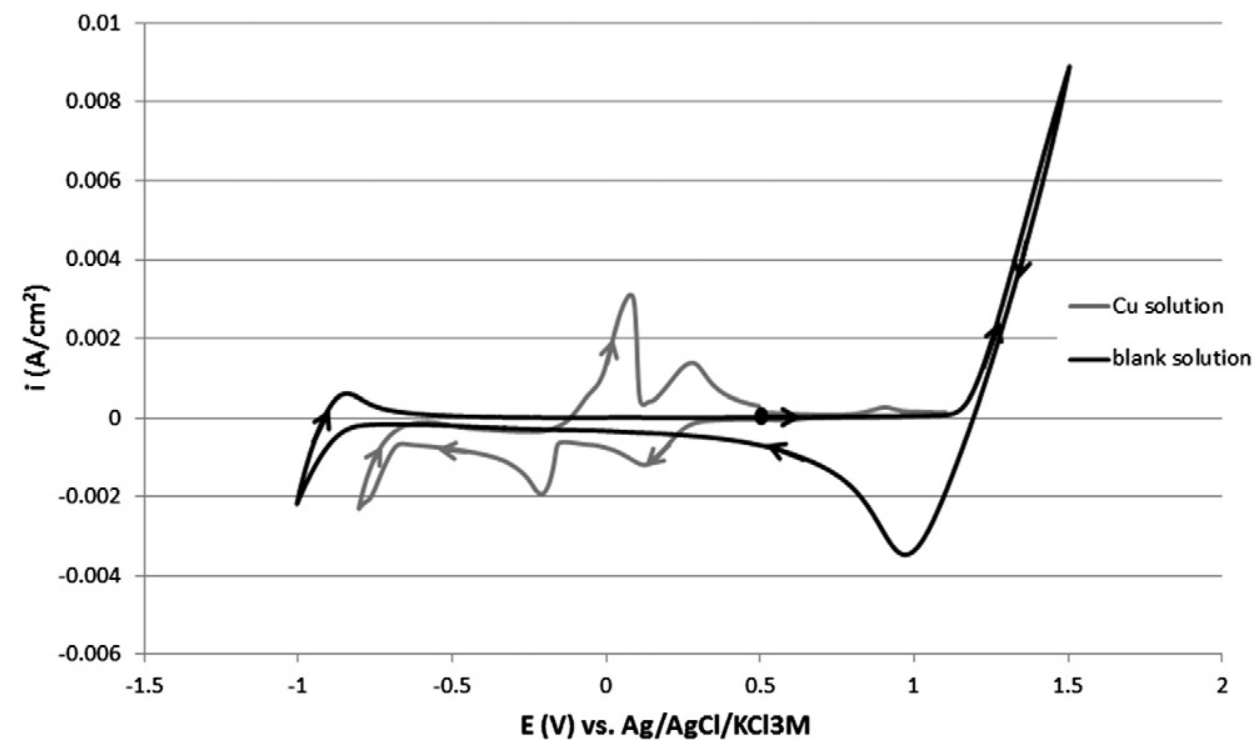

Fig. 3. Cyclic voltammograms obtained in the "blank" and "Cu" synthetic solutions. 


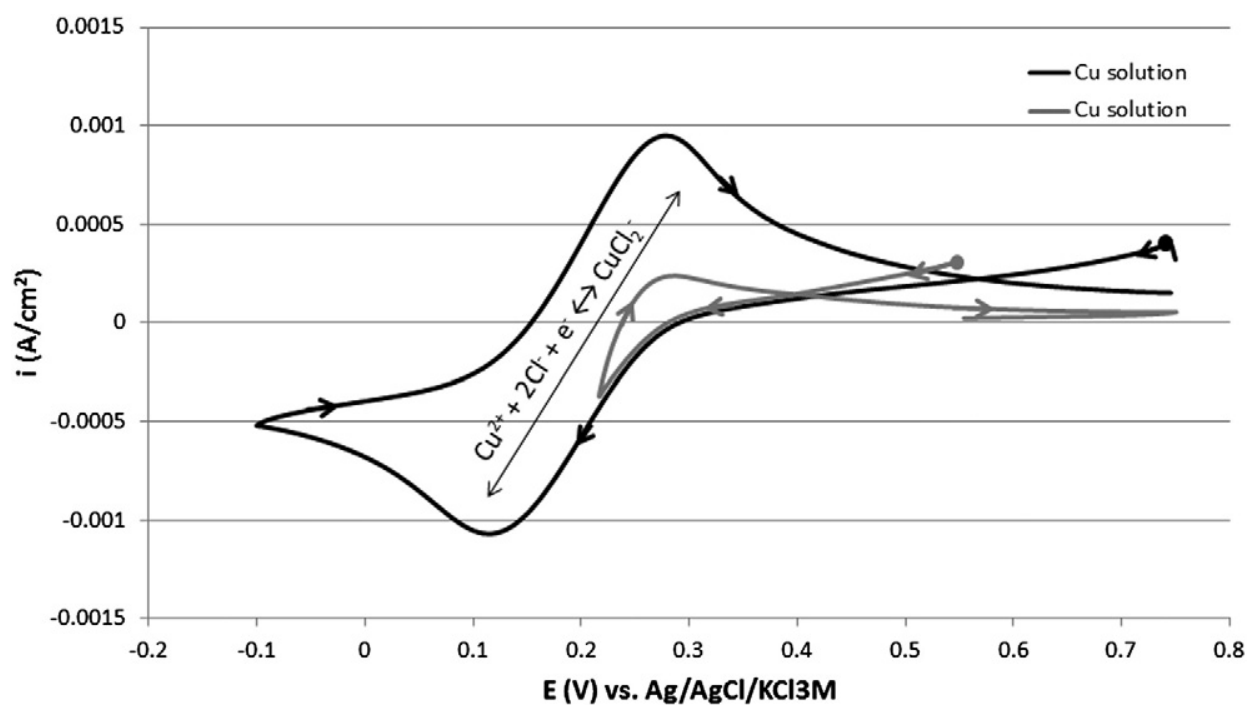

Fig. 4. Cyclic voltammograms obtained in the "Cu" synthetic solution for the study of the first reduction peak.

solutions with different pH values (Crousier et al., 1988; Crundwell, 1991; Deluis et al., 1993).

The cyclic voltammogram obtained in the Au synthetic solution compared to the voltammogram of the blank solution is reported in Fig. 6. Two new peaks are observed which do not correspond to the reactions involving the Pt oxide. A reduction peak at about $0.55 \mathrm{~V}$ vs. $\mathrm{Ag} / \mathrm{AgCl} / \mathrm{KCl}_{3 \mathrm{M}}$ and its corresponding oxidation peak at about $0.95 \mathrm{~V}$ vs. $\mathrm{Ag} / \mathrm{AgCl} / \mathrm{KCl}_{3 \mathrm{M}}$. The two peaks are more clearly visible in Fig. 7 (black curve). The formal potential for the reduction of auric chloride complex in acid solution

$\mathrm{AuCl}_{4}^{-}+3 \mathrm{e}^{-} \rightarrow \mathrm{Au}^{0}+4 \mathrm{Cl}^{-}$

is $0.8 \mathrm{~V}$ vs. $\mathrm{Ag} / \mathrm{AgCl} / \mathrm{KCl}_{3 \mathrm{M}}$ (Inzelt, 2006). In our case the anodic peak is shifted to more positive potential values due to the difference between formal potential and anodic potential and the potential scan rate used. In order to evaluate whether the observed peak corresponds to the reduction of auric chloride to gold the scanning has been stopped at
$0.43 \mathrm{~V}$ vs. $\mathrm{Ag} / \mathrm{AgCl} / \mathrm{KCl}_{3 \mathrm{M}}$ and kept at this value for $15 \mathrm{~min}$. The working electrode has been taken out from the solution and analysed by SEMEDXS. The results are reported in Fig. 8. As can be observed by the EDXS results (analysis performed on the full section observed in the micrograph) the electrode surface is covered by a thin film of Au demonstrating that the reduction peak at $0.55 \mathrm{~V}$ vs. $\mathrm{Ag} / \mathrm{AgCl} / \mathrm{KCl}_{3 \mathrm{M}}$ corresponds to the reduction of $\mathrm{AuCl}_{4}^{-}$. The observed shift could be attributed to the presence of $\mathrm{NO}_{3}^{-}$in the solution.

3.3. Cyclic voltammetry in $\mathrm{Cu}+\mathrm{Au}$ synthetic solution - effect of temperature and stirring

From the analyses of the single metal synthetic solutions it was clear that the only metal which could interfere with the deposition of Au was $\mathrm{Cu}$, as there could be a possible overlapping of the first reduction peak of $\mathrm{Cu}^{2+}$ with the reduction peak of $\mathrm{AuCl}_{4}^{-}$. For this reason the $\mathrm{Cu}+\mathrm{Au}$ solution (Table 2) was prepared. The voltammogram obtained in the $\mathrm{Cu}+$ Au solution in a potential range from -0.8 to $1.3 \mathrm{~V}$ vs.

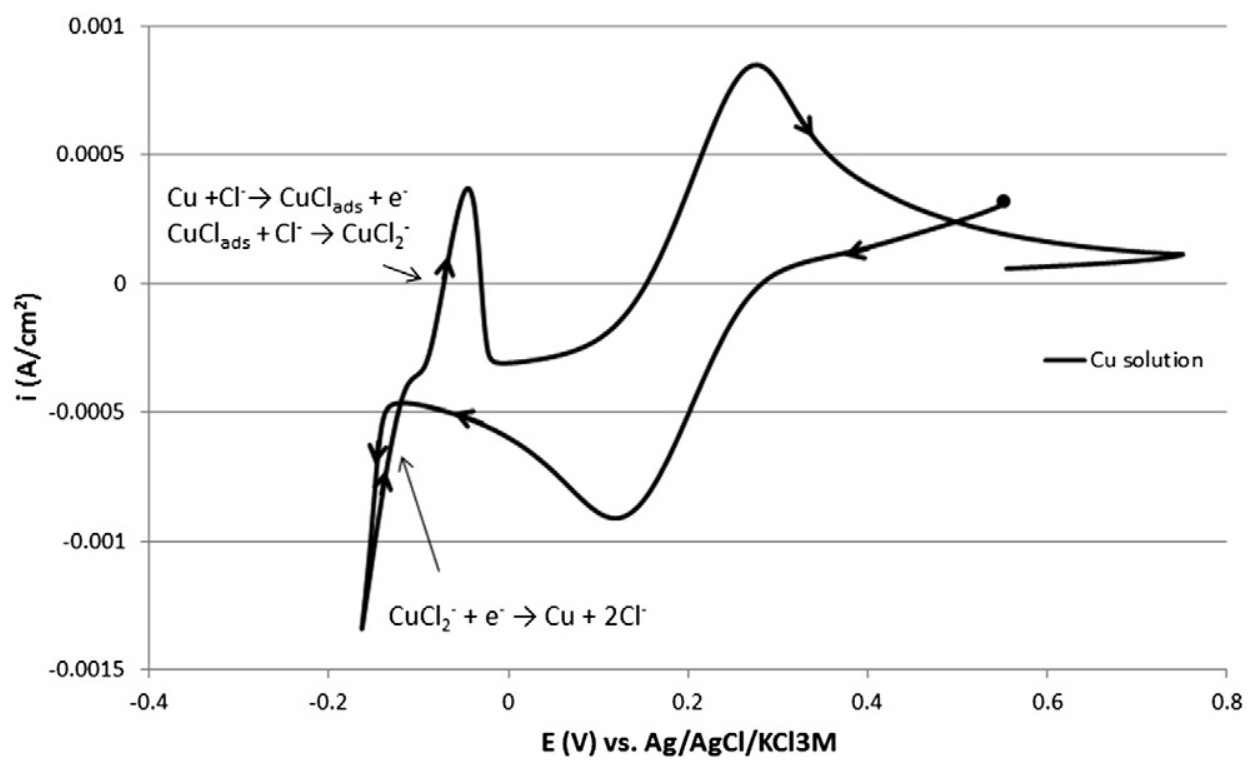

Fig. 5. Cyclic voltammograms obtained in the "Cu" synthetic solution for the study of the second reduction peak. 


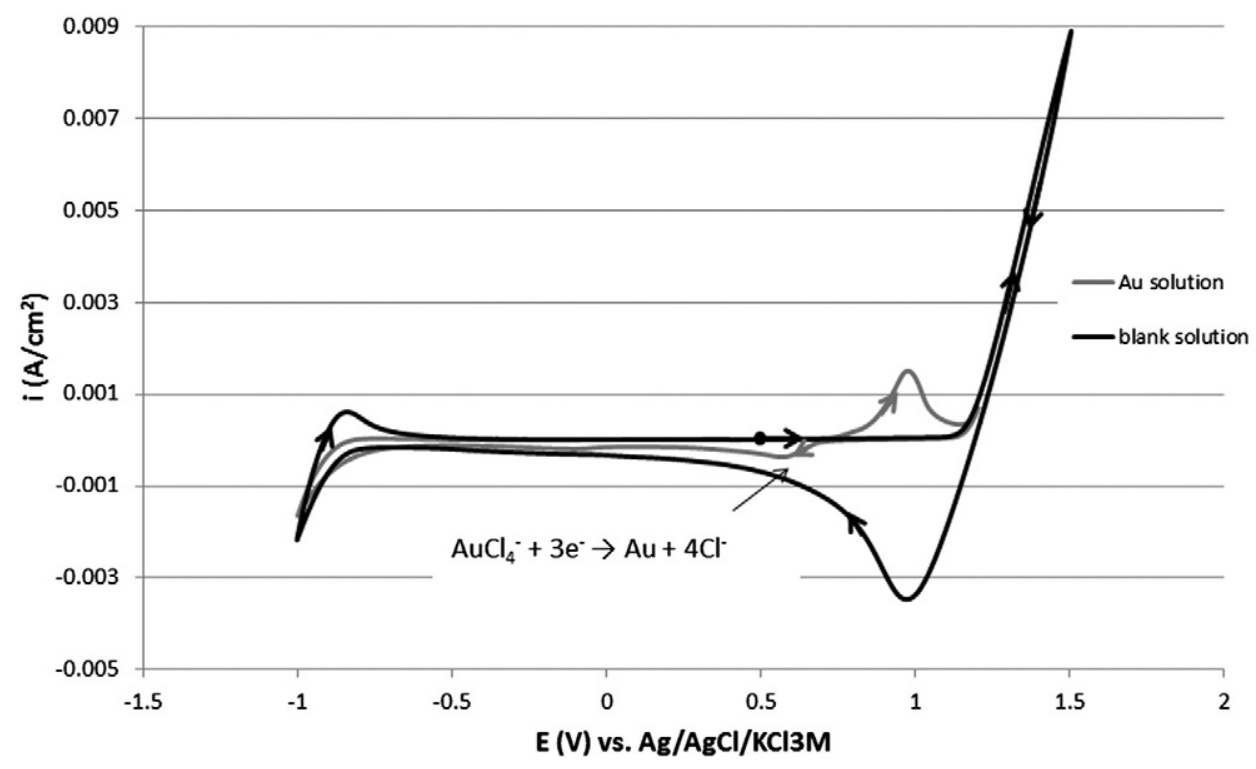

Fig. 6. Cyclic voltammograms obtained in the "blank" and "Au" synthetic solutions.

$\mathrm{Ag} / \mathrm{AgCl} / \mathrm{KCl}_{3 \mathrm{M}}$ is reported in Fig. 9. Four reduction and four oxidation peaks are observed. According to the previous analyses the reduction peak at about $0.57 \mathrm{~V}$ and the corresponding oxidation peak at about $0.8 \mathrm{~V}$ vs. $\mathrm{Ag} / \mathrm{AgCl} / \mathrm{KCl}_{3 \mathrm{M}}$ are attributed to the reduction of the auric chloride according the reaction (6). The reduction peaks at about 0.12 and $-0.21 \mathrm{~V} v \mathrm{vs} . \mathrm{Ag} / \mathrm{AgCl} / \mathrm{KCl}_{3 \mathrm{M}}$ and the corresponding oxidation peaks at 0.17 and $0.35 \mathrm{~V}$ vs. $\mathrm{Ag} / \mathrm{AgCl} / \mathrm{KCl}_{3 \mathrm{M}}$ correspond to the reduction and oxidation reactions of copper being the pair of cathodic and anodic peaks at about $0.12 \mathrm{~V}$ and $0.35 \mathrm{~V}$ related to the copper soluble species (Eq. (2)). The reduction peak at $-0.74 \mathrm{~V}$ and the corresponding oxidation peak at $-0.70 \mathrm{~V}$ are related to the reduction and oxidation of hydrogen. The presence of both metals in the solution caused a shift of all peaks to more positive potentials.

Further measurements have been performed in the potential range concerning the Au peaks by varying the temperature and the stirring rate (Fig. 10). The magnetic stirring caused some noise to the voltammograms but the effect of both stirring and temperature can be noticed. At $25^{\circ} \mathrm{C}$ a slight increase of both reduction and oxidation current values is observed as a function of the stirring rate. This increase becomes more intense at $40{ }^{\circ} \mathrm{C}$ indicating a diffusion controlled process. A further increase of the temperature, above $40{ }^{\circ} \mathrm{C}$ caused a strong precipitation in the testing solution, while further increase in the stirring rate leads to a turbulent flow in the electrochemical cell. Based on the cyclic voltammetric results a deposition has been performed at $0.4 \mathrm{~V}$ vs. $\mathrm{Ag} /$ $\mathrm{AgCl} / \mathrm{KCl}_{3 \mathrm{M}}$ for $60 \mathrm{~min}$ at $40{ }^{\circ} \mathrm{C}$ and $300 \mathrm{rpm}$. After the deposition the cathode was covered by an apparently compact dark yellow deposit. The obtained deposit was analysed by SEM and EDXS. The SEM micrographs and the EDX spectrum obtained on the full section observed in the micrograph are reported in Fig. 11. The EDXS analyses reveal no other elements except $\mathrm{Au}, \mathrm{Pt}$ and $\mathrm{Rh}$ deriving from the substrate. The gold deposit showed a nano-crystalline structure and covers uniformly the whole electrode surface.

\subsection{Cyclic voltammetry in PCB and contact leach solutions}

Cyclic voltammograms obtained both in the PCB and in the contact solutions are reported in Fig. 12. In both voltammograms the reduction

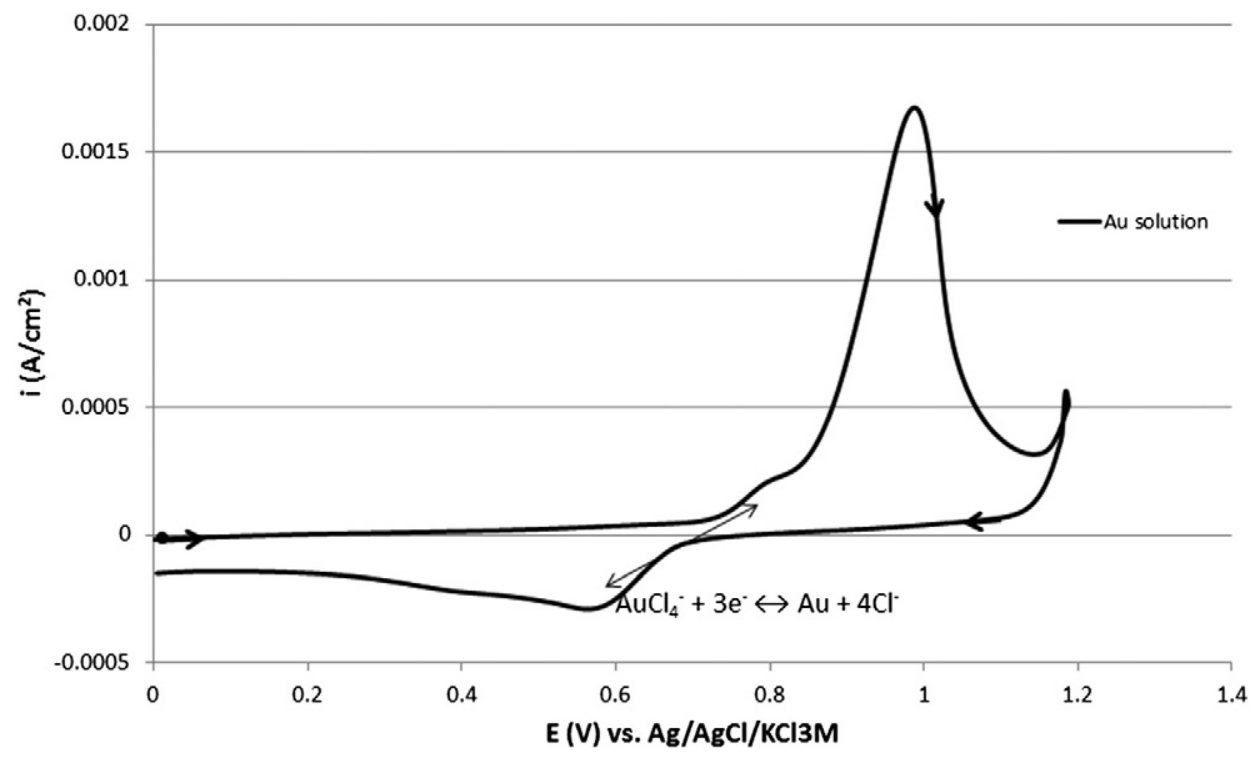

Fig. 7. Cyclic voltammetry study of the Au reduction peak in the synthetic "Au" solution and deposition conditions. 


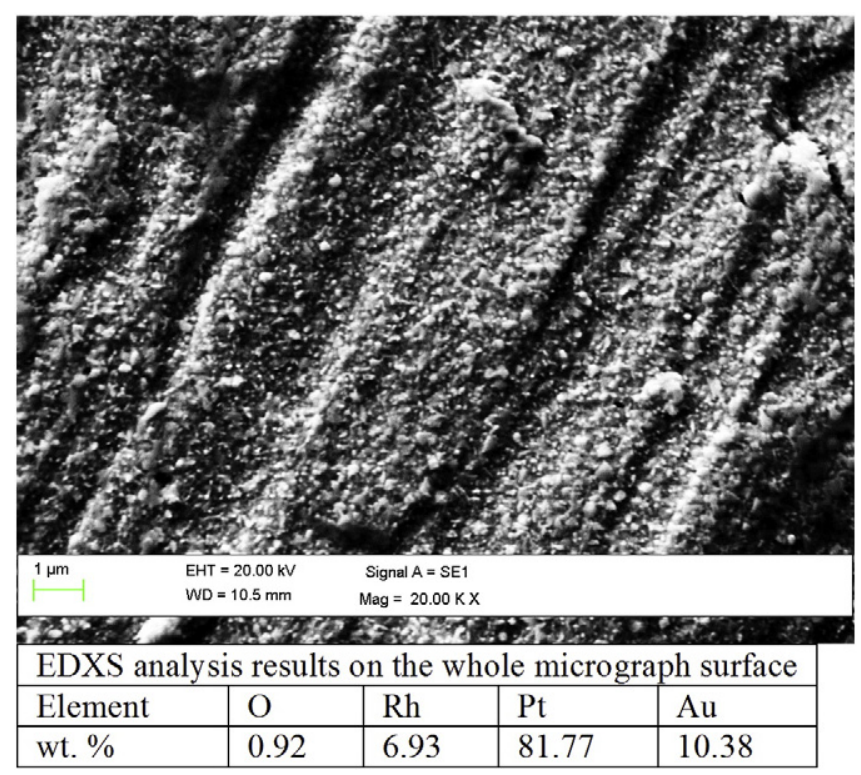

Fig. 8. SEM micrograph and EDXS results of the electrode surface after deposition from the "Au" synthetic solution at $0.43 \mathrm{~V}$ vs. $\mathrm{Ag} / \mathrm{AgCl} / \mathrm{KCl}_{3 \mathrm{M}}$ for $15 \mathrm{~min}$.

peaks of $\mathrm{Cu}$ at about $0.37 \mathrm{~V}$ and $-0.2 \mathrm{~V}$ vs. $\mathrm{Ag} / \mathrm{AgCl} / \mathrm{KCl}_{3 \mathrm{M}}$ and the corresponding oxidation peaks at $0.28 \mathrm{~V}$ and $-0.17 \mathrm{~V} \mathrm{vs}$. $\mathrm{Ag} / \mathrm{AgCl} / \mathrm{KCl}_{3 \mathrm{M}}$ can be noticed. The higher concentration of $\mathrm{Cu}$ in the contact solution (Table 3 ) leads to a higher current at both reduction and oxidation peaks. The reduction peak of Au cannot be distinguished in either of the two voltammograms. Moreover, different reduction peaks are visible, overlapping the $\mathrm{H}^{+}$peak at more negative potentials, more evident in the cyclic voltammograms of the contact solution voltammogram. When the scan is inversed three more oxidation peaks appear at $0.11 \mathrm{~V}, 0.18$ and $0.75 \mathrm{~V}$ vs. $\mathrm{Ag} / \mathrm{AgCl} / \mathrm{KCl}_{3 \mathrm{M}}$, partially overlapping the copper oxidation peaks. These oxidation peaks have not been observed in the voltammograms obtained in the synthetic solution and could thus correspond to other metals present in the leach solutions. When the scan was performed in a shorter range, concerning mainly copper and gold these peaks disappeared, indicating that they belong to elements whose reduction occurs in much lower potentials (Fig. 13).

By performing cyclic voltammograms in the potential range around $0.65 \mathrm{~V} \mathrm{vs}$. $\mathrm{Ag} / \mathrm{AgCl} / \mathrm{KCl}_{3 \mathrm{M}}$, where the reduction peak of Au was observed in the synthetic solution consisting of $\mathrm{Cu}$ and $\mathrm{Au}$, in both leach solutions (PCBs and contacts), no peaks have been observed (Fig. 14). This could be attributed to the low concentration of Au in the leach solutions or to the presence of other elements which could have shifted the reduction peaks of $\mathrm{Au}$ and $\mathrm{Cu}$. In order to individuate the reduction peak of $\mathrm{Au}$, the contact leach solution has been enriched in Au using the synthetic $\mathrm{Au}$ solution and a cyclic voltammogram was obtained in the potential range from $0.5 \mathrm{~V}$ to $1.1 \mathrm{~V}$ vs. $\mathrm{Ag} / \mathrm{AgCl} / \mathrm{KCl}_{3 \mathrm{M}}$ (Fig. 15). As can be observed a reduction peak at about $0.55 \mathrm{~V}$ and the corresponding oxidation peak at about $0.78 \mathrm{~V}$ and $0.96 \mathrm{~V}$ vs. $\mathrm{Ag} / \mathrm{AgCl} / \mathrm{KCl}_{3 \mathrm{M}}$ appear. The reduction peak could correspond to the reduction of Au according to reaction (6), but is overlapping the first reduction peak of $\mathrm{Cu}$ (reaction (2)). The presence of other elements in the solution, the low concentration of Au and the higher ratio between $\mathrm{Cu}$ and $\mathrm{Au}$ concentrations caused a shift of the auric chloride complex to more negative values and a shift of the reduction peak of $\mathrm{Cu}$ to more positive values. As the concentration of $\mathrm{Cu}$ was much higher than in the synthetic solution the reduction peak of auric chloride was hindered by the reduction peak of $\mathrm{Cu}$ which appears broader.

In order to confirm this hypothesis a deposition was performed using the contact solution at $0.55 \mathrm{~V}$ vs. $\mathrm{Ag} / \mathrm{AgCl} / \mathrm{KCl}_{3 \mathrm{M}}$ for $3 \mathrm{~h}$, even though the reduction peak of Au was not evident. The PCB solution was not used for this test as the Au concentration was ten times lower in comparison to the contact solution. At the end of the deposition the cathode was covered by a dark yellow layer which has been analysed by SEM and EDXS. In Fig. 16 a SEM micrograph and an EDXS spectrum are reported. As can be observed the electrode surface is uniformly covered by a nanocrystalline deposit of pure Au. The EDXS analyses did not reveal the presence of other elements except Au and Pt (deriving from the substrate). From these analyses it was confirmed that the reduction peak of the auric chloride was hindered by the reduction peak of $\mathrm{Cu}^{2+}$ to $\mathrm{CuCl}_{2}^{-}$. However, the deposition of Au was possible, even with low efficiency, as the parallel, competitive reaction forms only soluble species. The reaction rate could be increased by increasing the temperature to $40{ }^{\circ} \mathrm{C}$ and the stirring rate according to the results obtained in the synthetic solutions.

\section{Conclusions}

PCBs can prove to be a very promising resource for the recovery of metals with high commercial value. Gold, among them, is usually present in a very low quantity and its recovery requires complex chemical treatments. The aim of this work was to evaluate the feasibility of

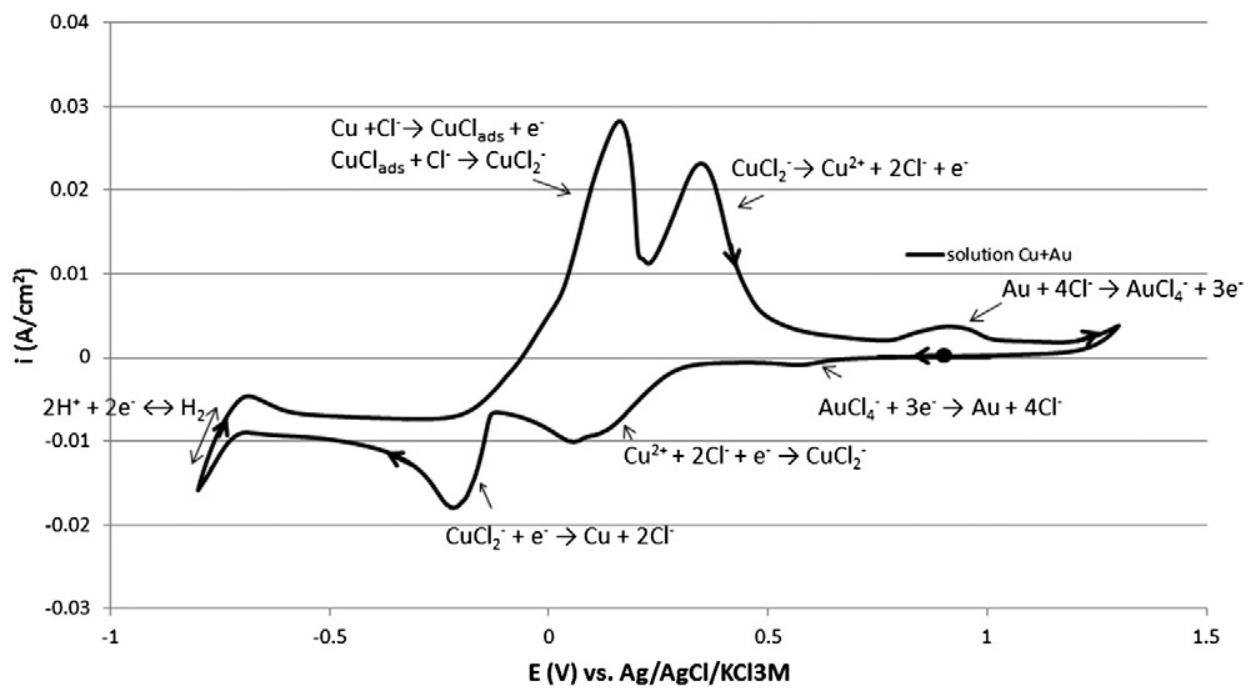

Fig. 9. Cyclic voltammogram obtained in the " $\mathrm{Cu}+\mathrm{Au}$ " synthetic solution. 

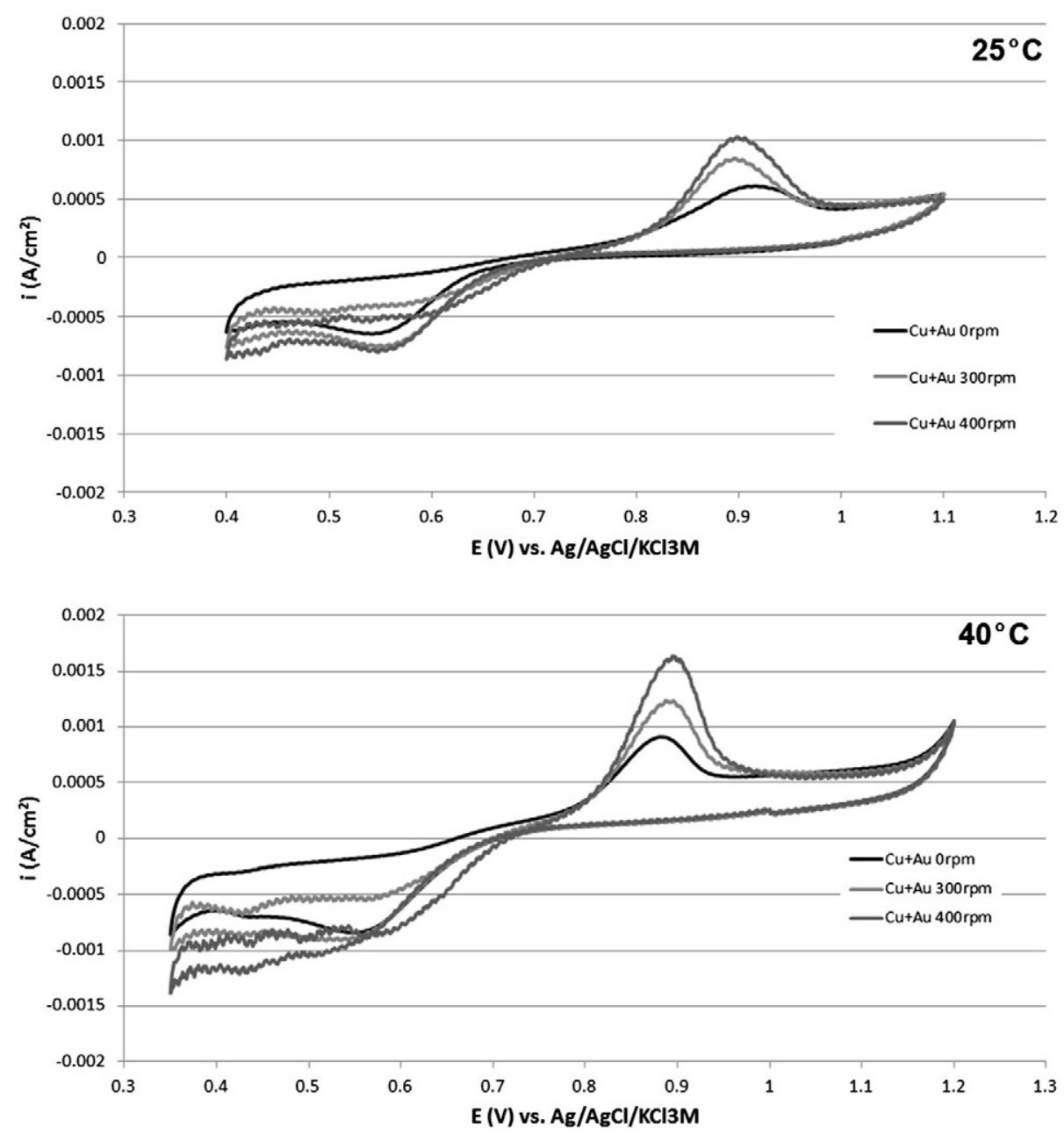

Fig. 10. Cyclic voltammograms for the study of the reduction peak of $\mathrm{Au}$ in the synthetic " $\mathrm{Cu}+\mathrm{Au}$ " solution by varying the temperature and the stirring rate.

recovering Au by electrodeposition from aqueous solutions obtained after leaching of PCBs and contacts prior to the recovery of any other metals. To this aim a preliminary study using synthetic solutions of

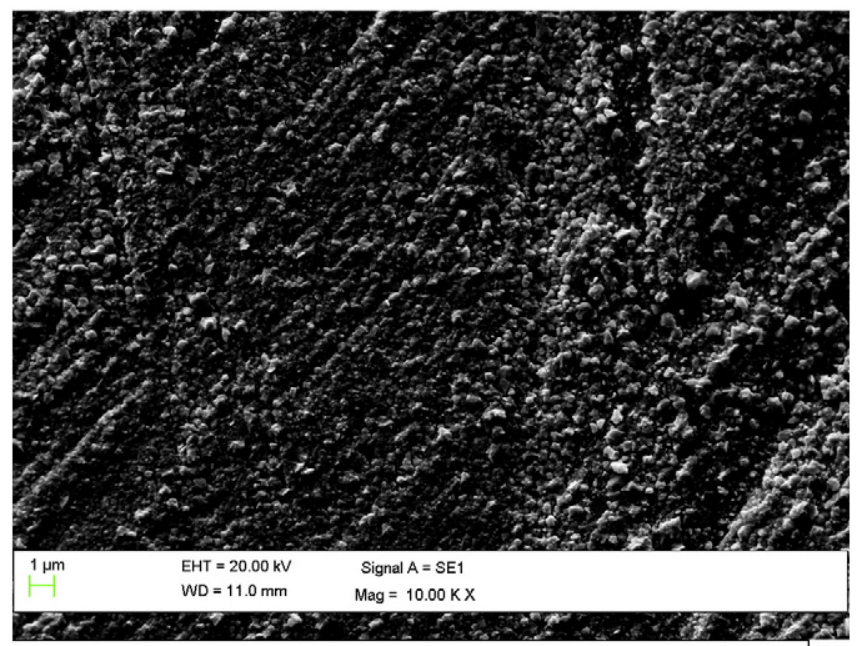

EDXS analysis results on the whole micrograph surface

\begin{tabular}{l|l|l|l}
\hline Element & Rh & $\mathrm{Pt}$ & $\mathrm{Au}$ \\
\hline wt. \% & 2.55 & 39.87 & 57.58 \\
\hline
\end{tabular}

Fig. 11. SEM micrograph and EDXS results of the electrode surface after deposition from the " $\mathrm{Cu}+\mathrm{Au}$ " synthetic solution at $0.4 \mathrm{~V}$ vs. $\mathrm{Ag} / \mathrm{AgCl} / \mathrm{KCl}_{3 \mathrm{M}}$ for $60 \mathrm{~min}$ at $40{ }^{\circ} \mathrm{C}$ and $300 \mathrm{rpm}$. the elements which could interfere with the gold deposition was performed, followed by an electrochemical study of leach solution of PCBs and contacts.

Aqua regia was proved to be an efficient leachant for the dissolution of all metals from powders obtained after thermal treatment of PCBs and contacts. Among the metals present in the leach solution only copper can interfere with the deposition of gold as the reduction peaks of the auric chloride complex and the $\mathrm{Cu}^{2+}$ ions are very close. The other metals present in the solution cause a potential shift of the reduction and oxidation peaks of both $\mathrm{Au}$ and $\mathrm{Cu}$. For this reason synthetic solutions containing single metals as well as $\mathrm{Cu}$ and $\mathrm{Au}$ have been used in order to study their electrochemical behaviour. It was found that $\mathrm{Cu}$ presents two reduction peaks for all solutions containing copper ions, the first between 0.12 and $0.15 \mathrm{~V}$ vs. $\mathrm{Ag} / \mathrm{AgCl} / \mathrm{KCl}_{3 \mathrm{M}}$ referred to the reduction of $\mathrm{Cu}^{2+}$ to $\mathrm{CuCl}_{2}^{-}$and the second between -0.21 and $-0.37 \mathrm{~V}$ vs. $\mathrm{Ag} / \mathrm{AgCl} / \mathrm{KCl}_{3 \mathrm{M}}$ referred to the deposition of $\mathrm{Cu}$. The reduction of the $\mathrm{AuCl}_{4}^{-}$to $\mathrm{Au}$ was detected at about $0.55 \mathrm{~V} \mathrm{vs.} \mathrm{Ag} / \mathrm{AgCl} / \mathrm{KCl}_{3 \mathrm{M}}$. A deposition at $0.4 \mathrm{~V}$ leads to the production of a nanocrystalline gold deposit of high purity. The deposition rate increases by increasing the temperature at $40^{\circ} \mathrm{C}$ and the stirring of the electrolyte.

The cyclic voltammetry measurement in the leach solutions of both PCBs and contacts revealed the presence of other elements whose reduction peaks appear in lower potential range and thus could not influence the deposition of Au. The high quantity of $\mathrm{Cu}$, the low quantity of $\mathrm{Au}$ and the presence of other elements lead to the broadening of the reduction peak of $\mathrm{Cu}^{2+}$ and a shift to more positive potentials and the shift of the reduction peak of $\mathrm{AuCl}_{4}^{-}$to less positive potentials. This led to an almost complete overlapping of the two reduction peaks. 


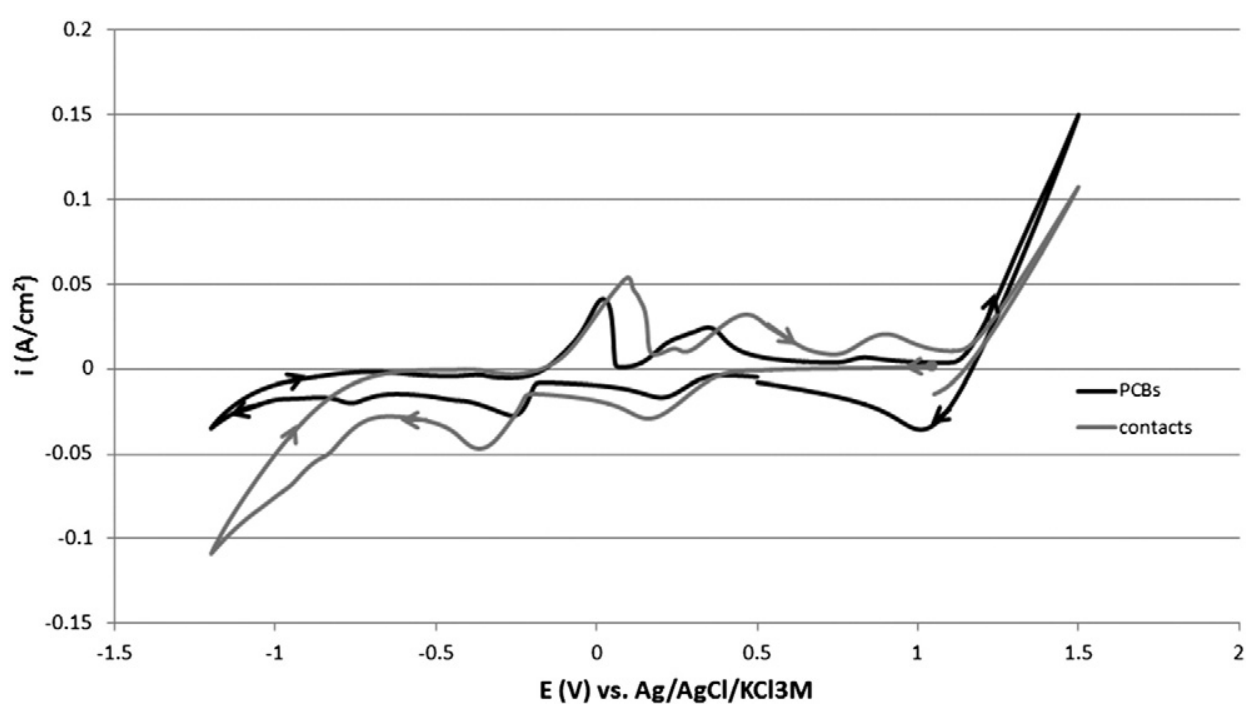

Fig. 12. Cyclic voltammograms obtained in the PCB and contact leach solutions.

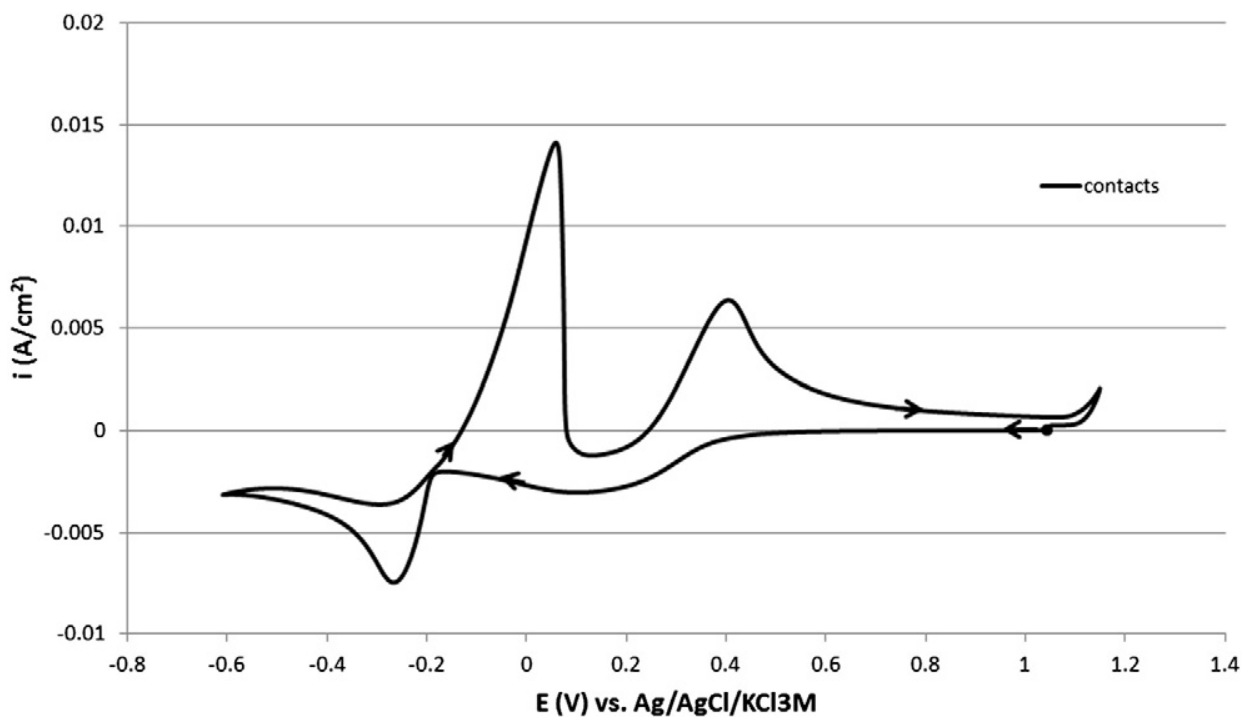

Fig. 13. Cyclic voltammogram obtained in the contact leach solution in a potential range from $-0.6 \mathrm{~V}$ to $1.2 \mathrm{~V} \mathrm{vs}$. $\mathrm{Ag} / \mathrm{AgCl} / \mathrm{KCl} 3 \mathrm{M}$.

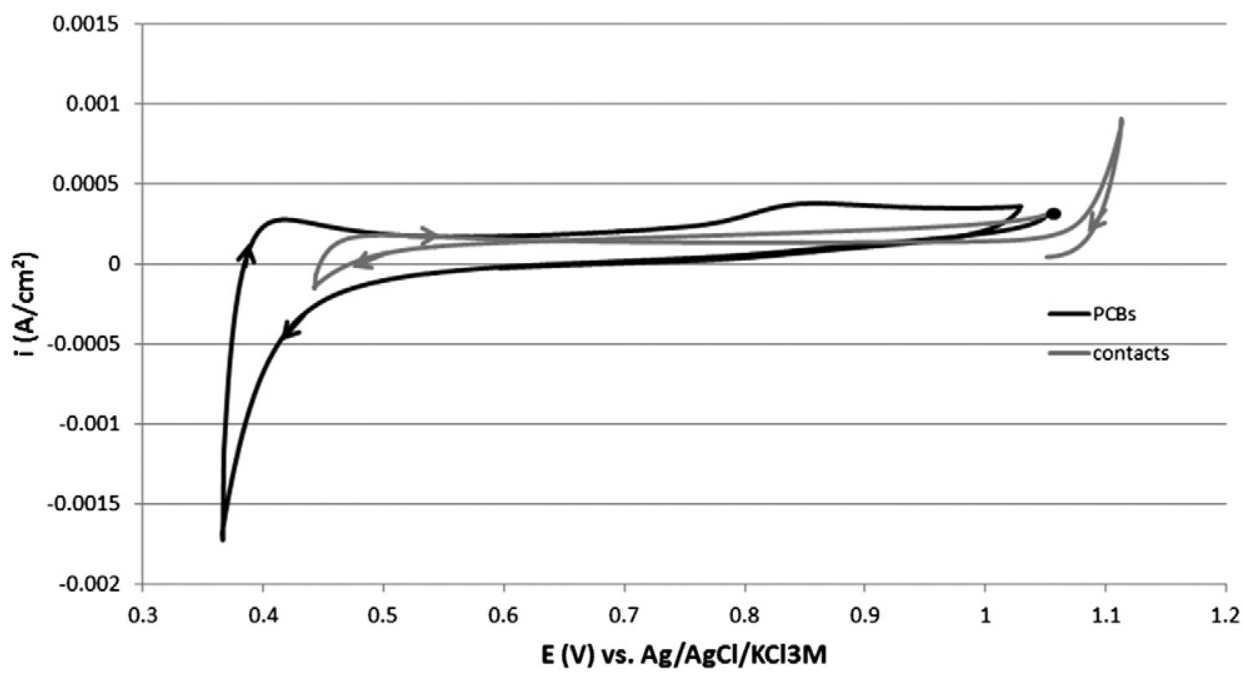

Fig. 14. Cyclic voltammograms obtained in the $\mathrm{PCB}$ and contact leach solution in a potential range from $0.35 \mathrm{~V}$ to $1.1 \mathrm{~V} \mathrm{vs}$. $\mathrm{Ag} / \mathrm{AgCl} / \mathrm{KCl} 3 \mathrm{M}$. 


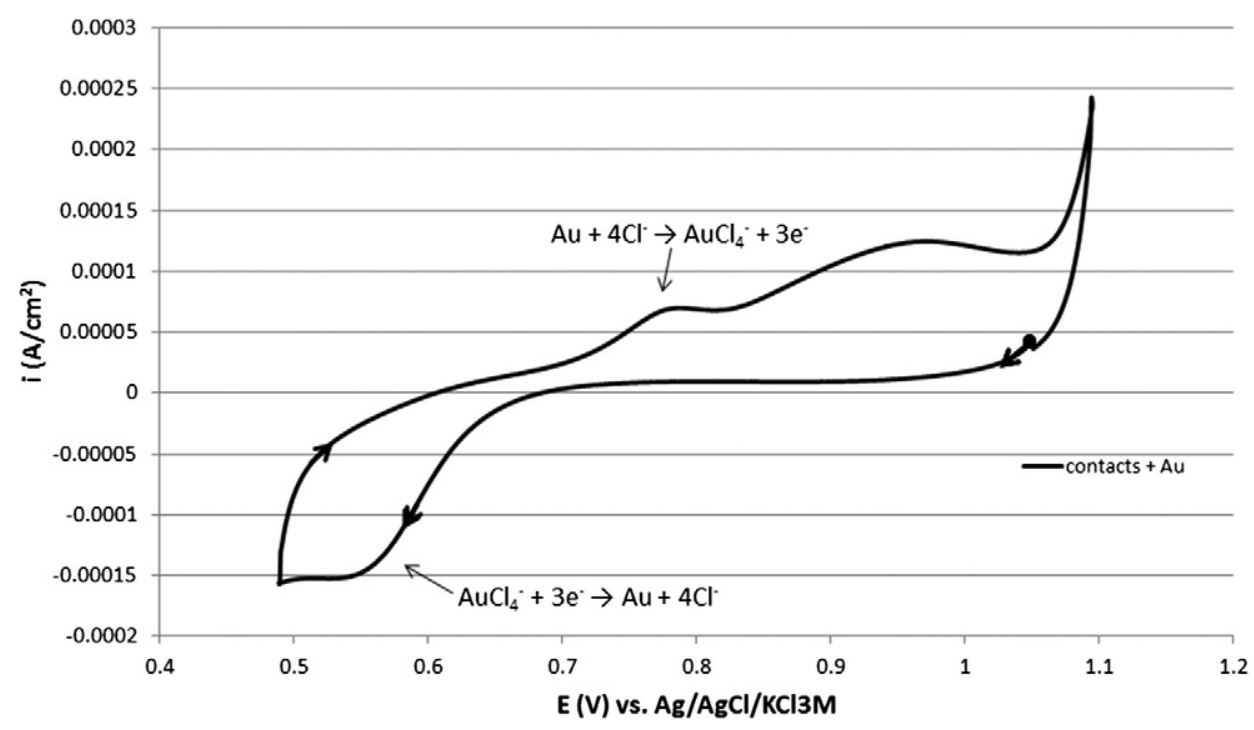

Fig. 15. Cyclic voltammogram obtained in the contact leach solution enriched in Au using the "Au" synthetic solution.

However, the deposition of Au was possible, even with low efficiency, as the parallel, competitive reaction forms only soluble species. A compact nanocrystalline deposit of high purity gold has been obtained by electrodeposition at $0.55 \mathrm{~V} \mathrm{vs}$. $\mathrm{Ag} / \mathrm{AgCl} / \mathrm{KCl}_{3 \mathrm{M}}$ from the contact leach solution. Traces of no other elements were detected by EDXS analyses in the obtained deposit despite their high concentration in the leach solution.

Therefore, this study demonstrates the feasibility of gold recovery from PCB and contact leach solutions by electrodeposition, without any further chemical treatment.

\section{Acknowledgement}

The authors would like to acknowledge Dr. Brandon De Voeght from Materia Nova Material R\&D Centre in Mons Belgium for the ICP measurements and CNPq-Brazil (Proc. 305890/2010-7).

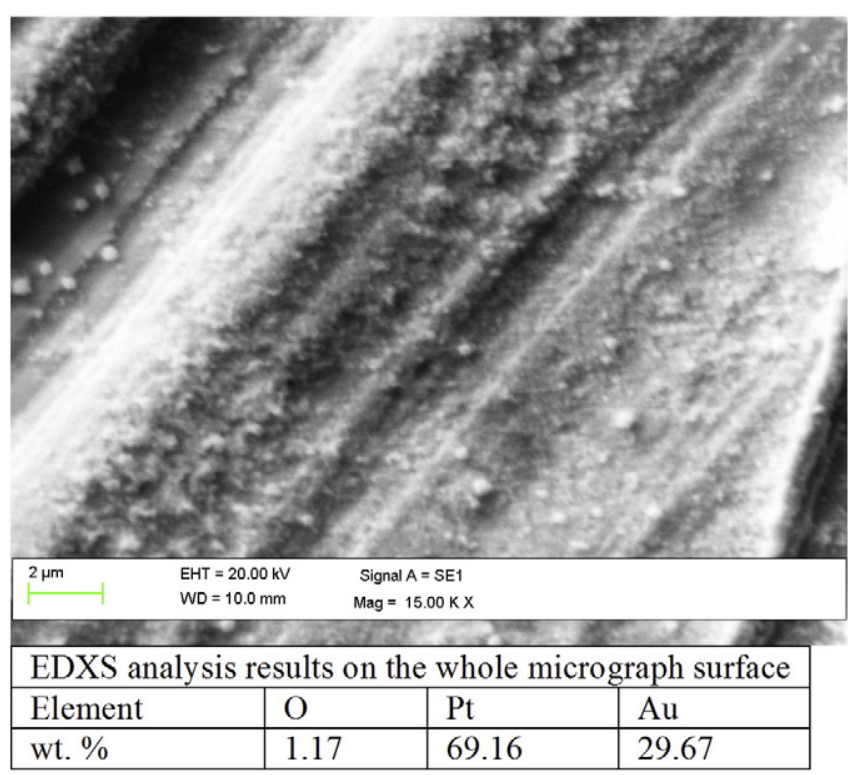

Fig. 16. SEM micrograph and EDXS results of the electrode surface after deposition from the contact leach solution at $0.55 \mathrm{~V}$ vs. $\mathrm{Ag} / \mathrm{AgCl} / \mathrm{KCl}_{3 \mathrm{M}}$ for $3 \mathrm{~h}$.

\section{References}

Angerstain-Kozlowska, H., Conway, B.E., Sharp, W.B.A., 1995. J. Electroanal. Chem. 43, 9. Barbieri, L., Giovanardi, R., Lancellotti, I., Michelazzi, M., 2010. A new environmental friendly process for the recovery of gold from electronic waste. Environ. Chem. Lett. 8, 171-178. Crousier, J., Pardessus, L., Crousier, J.P., 1988. Electrochim. Acta 33, 1039.

Crundwell, F.A., 1991. Electrochim. Acta 36, 1183.

Cui, J., Forssberg, E., 2003. Mechanical recycling of waste electric and electronic equipment: a review. J. Hazard. Mater. B99, 243-263.

Deluis, C., Mattos, O.R., Mousiani, M.M., Tribollet, B., 1993. Electrochim. Acta 38, 2781.

Directive 2002/95/EC, 2003. On the restriction of use of certain hazardous substances in electrical and electronic equipment.

Directive 2003/95/EC, 2003. On Waste Electrical and Electronic Equipment (WEEE).

Directive 2011/65/EU, 2011. On the Restriction of Use of Certain Hazardous Substances in Electrical and Electronic Equipment (Recast).

Directive 2012/19/EU, 2012. On Waste Electrical and Electronic Equipment (WEEE) (Recast). Horányi, G., Aramata, A., 1997. J. Electroanal. Chem. 434, 201.

http://ec.europa.eu/environment/waste/weee/index_en.htm.

Inzelt, G., 2006. In: Geiger, W.E., Pickett, C. (Eds.), Standard, formal and other characteristic potentials of selected electrode reactions. Encyclopedia of Electrochemistry 2 (7), pp. 17-75.

Khaliq, A., Rhamdhani, M.A., Brooks, G., Masood, S., 2014. Metal extraction processes for electronic waste and existing industrial routes: a review and Australian perspective. Resources 3, 152-179.

Linton, J., 2000. Electronic products at their end-of-life: options and obstacles. J. Electron. Manuf. 9, 29-40.

Masavetas, I., Moutsatsou, A., 2009. Sampling, classification and characterization of Waste Electrical and Electronic Equipment for recycling and recovery of metals. IMA'09 Athens, Greecep. 275.

Masavetas, I., Moutsatsou, A., 2011. Application of the Taguchi Method for Design of Experiments for Optimization of the Dissolution Process of WEEE for the Production of Metal Powder. SDEWES, Dubrovnik, Croatia, p. 230.

Masavetas, I., Moutsatsou, A., Nikolaou, E., Spanou, S., Zoikis-Karathanasis, A., Pavlatou, E.A., Spyrellis, N., 2009. Production of copper powder from printed circuit boards by electrodeposition. Glob. Nest J. 11 (2), 241-247.

Mascaro, L.H., Santos, M.C., Machado, S.A.S., Avaca, L.A., 2002. J. Braz. Chem. Soc. 13, 529

Mecucci, A., Scott, K., 2002. Leaching and electrochemical recovery of copper, lead and tin from scrap printed circuit boards. J. Chem. Technol. Biotechnol. 77, 449-457.

Oishi, T., Koyama, K., Alam, S., Tanaka, M., Lee, J.-C., 2007. Recovery of high purity copper cathode from printed circuit boards using ammoniacal sulfate or chloride solutions. Hydrometallurgy 89, 82-88.

Park, S.Y.J., Fray, D.J., 2009. Recovery of high purity precious metals from printed circuit boards. J. Hazard. Mater. 164, 1152-1158.

Qinet, P., Proost, J., Van Lierde, A., 2005. Recovery of precious metals from electronic scrap by hydrometallurgical processing routes. Miner. Metall. Process. 22 (1), 17-22.

Sawyer, D.T., Sobkowiak, A., Roberts, J.L., 1995. Electrochemistry for Chemists. Second edition. John Wiley \& Sons, Inc., NY.

Sheng, P.P., Etsell, T.H., 2007. Recovery of gold from computer circuit board scrap using aqua regia. Waste Manag. Res. 25 (4), 380-383.

Sum, E.Y.L., 1991. The recovery of metals from electronic scrap. JOM 43, 53-61.

Veit, H.M., Bernardes, A.M., Ferreira, J.Z., Tenorio, J.A.S., de Fraga Malfatti, C., 2006. Recovery of copper from printed circuit boards scraps by mechanical processing and electrometallurgy. J. Hazard. Mater. B 137, 1704-1709.

Zhang, S., Fosseberg, E., 1997. Mechanical separation-oriented characterization of electronic scrap. Resour. Conserv. Recycl. 21, 247-269. 